\title{
The Transformation of Appropriation in Contemporary Art
}

\author{
Dai Xiaoling, Kan Qing* \\ School of Fine Arts, Nanjing Normal University, Nanjing, China \\ Email address: \\ daixiaoling970116@outlook.com (Dai Xiaoling), Kanqing777@qq.com (Kan Qing) \\ ${ }^{*}$ Corresponding author Kan Qing
}

\section{To cite this article:}

Dai Xiaoling, Kan Qing. The Transformation of Appropriation in Contemporary Art. International Journal of Literature and Arts.

Vol. 8, No. 4, 2020, pp. 255-259. doi: 10.11648/j.ijla.20200804.21

Received: June 21, 2020; Accepted: July 4, 2020; Published: July 28, 2020

\begin{abstract}
Appropriation is one of the most commonly used techniques in contemporary art. It can be seen in various art forms, such as painting, sculpture, photography, video. Due to the emergence of appropriation, artists have great opportunities to lend fresh perspectives to pre-existing objects and images and can embody new sentiments in their creations. Since Marcel Duchamp's ready-mades were introduced to the art world, they had considerable influence on the appropriation over the past 100 years. The first section of this study is to analyse the current situation of appropriation in contemporary art by comparing two ready-mades of Marcel Duchamp and Maurizio Cattelan. In the second section, the focus will be on the aesthetic transformation of appropriation, which encompasses ready-mades, signs and phenomena. Due to significant transformations, appropriation is not confined to artistic creations, and it can be seen in the production of popular culture. The last section of this study will investigate the influence of appropriation on popular culture by taking popular brand Supreme as an example. Addressing this transformation will enable a comprehensive understanding of how to use appropriation appropriately, helping creators to make full use of its merits, thus producing more emotional and meaningful works. This paper enable the author to reach the conclusion that excessive and inappropriate appropriations produce flawed works and can cultivate a misunderstanding of both the original works and the appropriation iteself.
\end{abstract}

Keywords: Appropriation, Contemporary Art, Transformation, Popular Culture

\section{Introduction}

With the emergence of a large number of associated practices, appropriation has become a heated and controversial topic in the art world. Appropriation refers to 'the practice of artists using pre-existing objects or images in their art with little transformation of the original.' [1] In the process of appropriation, artists attempt to challenge beliefs as to what constitute art history. When original works or ready-made products are separated from their established representation forms and contexts, they offer more possibilities for various artistic creations. In the context of postmodernism, almost everything can be appropriated into various creations. However, artists or creators who lack original visions are likely to produce works of repetitive forms of appropriation. The aims of this paper are to examine the development of appropriation in artistic creations and popular culture and explore the influence of this increasingly popular technique.

\section{Appropriation in Contemporary Art}

Marcel Duchamp was a pioneer of appropriation throughout art history. His Fountain questioned the accepted artistic conceptions in a subversive form, demonstrating the critical value of the urinal. The practice of directly appropriating ready-made products, appropriation gradually evolved into an important visual creative technique in contemporary art. Since then, a great variety of art techniques gradually have emerged and reshaped the discourse of art from a rebellious standpoint.

A number of decades later, artist Maurizio Cattelan's work Comedian featured a banana taped to a wall and sold for $\$ 120,000$ [2] at Art Basel Beach on December 5 2019, receiving significant public attention. However, this banana was nothing but a common item widely available at fruit market. Unexpectedly, the banana was eaten by the artist David Datuna two days later and he considered himself to be a hungry artist. Can this banana, directly borrowed from 
everyday life, be regarded as a work of art? If the answer is 'yes', can we call all works of appropriation works of art?

When spoke of Comedian, the creator Maurizio Cattelan once said, 'We share genuine respect toward what preceded us, and at the same time, we are staunch supporters of the idea that the copy is the original. We found ourselves halfway, where iconography meets icons, and where celebrated originals become timeless icons through a simple act of repetition and propagation.' [3] In this sense, he believed that copies also have original values. Although appropriation works are produced under different contexts and the meanings carried by the original works may be changed or even distorted, these do not affect the feelings and emotions they convey.

The rise of modernism promoted the development of appropriation, but led to some negative aspects. In France, the 1990s brought considerable upheavals to the art world, including controversial aesthetic standards, concepts, and forms. When it comes to contemporary art, Arthur C. Danto wrote, 'contemporary has come to designate something more than simply the art of the present moment.' [4] He also argued, 'Much of contemporary art is hardly aesthetic at all, but it has in its stead the power of meaning and the possibility of truth, and depends upon the interpretation that brings these into play. [5] In this light, contemporary art contributed to the ambiguity of traditional aesthetic attitudes and art forms. Because of the openness and diversity brought about by contemporary art, appropriation has been used unscrupulously by artists and the public nowadays.

The aforementioned practices of appropriating ready-mades into creations encourage artists to innovatively shift conventional artistic paradigms. But it also raise a question whether everything is entitled to artistic creations by virtue of appropriation. Currently, a great variety of appropriation works become prevalent and controversial in contemporary art. For example, one of the most controversial works by artist Jeff Koons, Rabbit was sold for more than \$91 million [6] in 2019 , setting a new record for living artists and global works of art. The excessive acts of appropriation and considerable financial returns gained by well-known artists are likely to lead to the misunderstanding that anything can be appropriated into artistic works. It may put the essence of art and the functions of artists at risk.

\section{The Aesthetic Transformation of Appropriation}

Marcel Duchamp made a place for himself in the appropriation movement. His ready-mades, such as Fountain, Bicycle Wheel broke the patterns of the received aesthetic paradigms and laid a solid foundation for the transformation of appropriation. Under the influence of social mechanisms, appropriation is not limited to ready-mades, and it tends to be symbolic and phenomenological and presents new artistic values by means of continuous deconstructions and reconstructions, which pave the way for the innovative development and exploration of contemporary art.
The creation of Fountain brought about a situation where the lines between ready-made products and works of art have been blurred, and the originality of artistic creations has been questioned. But such striking practice also encouraged the full development of appropriation and enriches the meanings of ready-made products. Art theorist Thierry de Duve once commented on Fountain, saying that it 'illustrates the undecidability, the openness, and the indeterminacy of the concept of art, or even its entrenchment in solipsism or its expansion into universal tautology.' [7] Therefore, the urinal got rid of its own physical functionality, destroying the noble and elegant aesthetic perceptions of former artists. The question and accompanying anger from the public and critics may encourage artists to perceive the existence of the unnoticed aspects of ordinary objects and tap into their inner powerful emotions, thus creating new forms and concepts for ready-made products.

As an artistic technique, appropriation can motivate artists to excavate the ignored aspects of ready-made products and everyday objects. Not all works of appropriation can be viewed as artworks. Artworks can produce a short period of silence for artists' and visitors' thoughts. To be specific, the difference between ready-made products and works of art is not in their physical properties, but in their hidden concepts.

Since the emergence of modern art, appropriation has become detached from the physical attributes of ready-made products and has gradually created its own discourse, evolving into a sign. Duchamp's actions made the urinal famous, and it became unique to Duchamp's artistic sign. Actually, the meaning of the urinal remains irreplaceable. The reason that Fountain can be considered as a sign is that it is indifferent without aesthetic emotions. When asked about the choice of ready-mades, Duchamp argued that, 'You have to approach something with indifference, as if you had no aesthetic emotion. The choice of ready-mades is always based on visual indifference and, at the same time, on the total absence of good or bad taste.'[8] For his perspective, when artists abandon their own fixed ideas, the sacredness and authority of art and treat all surrounding objects with equality or even with awe, they may discover the stillness and uniqueness of ready-made products.

Sign is an important topic in the field of semiotics. There are contradictory and supplementary concepts defined by Hegel, Peirce, Saussure, and other authors. For Saussure, the sign was not a specific thing, but a mental representation of a specific thing. Similarly, Roland Barthes used the example of a raincoat to show that the dual functions of sign are meaning and connotation. He wrote: 'But once the sign is constituted, society can very well re-functionalize it, and speak about it as if it were an object made for use...' [9] From his standpoint, signs can function as everyday objects and convey their meanings unconsciously. When an object becomes a sign, its boundaries are unclear, even ambiguous, and so is its the appropriation.

When the practice of appropriation becomes a sign, it means that the form of it is accepted by artists and the public. It also is likely to cause that hidden meanings of this practice 
is easily ignored. Many artists have developed in their own sign, such as Cindy Sherman's Untitled Film Stills, Richard Prince's re-photography of advertisements, and Sherrie Levine's After Walker Evans. These remarkable works challenge concepts of originality and make appropriation a controversial and polarised concept. If viewers focus too much on representative forms of appropriation, they are likely to believe that any kind of copy can be referred to as appropriation, even a work of art. At that time, the meaning and connotation that artists want to express by means of appropriation is ignored.

Since the boundaries between art and life become unclear, the wider acceptance of works of appropriation means that it is not confined to the role of a sign and, in turn, becoming a sought-after phenomenon. The appropriation of classic works has become a norm cross eras, which represents different styles of each period in the context of classical works. These practices have become an unconscious phenomenon in the evolution of art history. It is noteworthy that the concept of the phenomenon is at the core of Martin Heidegger's research. One of his theories suggested that phenomena are associated with the truth. He wrote, 'Specific phenomena are layered around "truth" insofar as knowing is achieved in the manner of articulating what is known, in putting what is known into a proposition, and insofar as this proposition is communicable and requires some comprehension for communication.' [10] In this light, many works of appropriation are created to show respect for original works. However, their meanings are ambiguous, meaning that their forms exceed the expression of truth. This is the reason that so many works of appropriation have emerged, but their connotations are unclear.

There is no doubt that this artistic phenomenon encourages artists to reflect on well-known classical works. The appropriation of historical paintings by photographer Cindy Sherman displays a unique perspective. The luxurious clothing and perfect bodies depicted in the original paintings were replaced with worn clothes, artificial limbs and wigs. In addition, the dignified and elegant characters were disfigured and converted into the opposite sex. All of these elements were satires on a historically male-dominated society. Appropriation from a different era may trigger excavations into the unnoticed layers of works of art in the process of continually denying classical works.

An issue that should not ignore is that once an artistic technique becomes a popular art phenomenon, it is easy to ignore the ontology of art, and appropriation should not become a shield for the lack of originality and meanings of artworks. Martin Heidegger's interpretation of artistic phenomenology is of great significance. His concepts of the origin of art are the most creative judgment on artistic phenomena. Heidegger said that 'The origin of the work of art - that is, the origin of both the creators and the preservers, which is to say of a people's historical existence - is art.' [11] Once an artistic technique becomes a phenomenon, it has already achieved widespread acceptance of artists and the public. As artists focus on exploring the origins of art, it becomes more likely that they will produce high-quality works of appropriation. The reason that many works of appropriation are indistinguishable from the next is that artists concentrate too much on form of representation, rather than on the origin of an artwork.

\section{The Crisis Between Appropriation and Popular Culture}

Since 1990s, consumer culture has gradually apread into the fields of art and culture, triggering the transformation and reconstruction of the aesthetic values and standards of contemporary art. So, appropriation has also been widely applied to popular culture. American critic Douglas Crimp discussed the status of appropriation: "For appropriation, pastiche, quotation-these methods can now be seen to extended to virtually every aspect of our culture, from the most cynically calculated products of the fashion and entertainment industries to the most committed critical activities of artists.' [12] As a product of widespread cultural phenomena and activities in contemporary society, popular culture represents the ideologies and mindsets of the public and the press of a given time by means of the medium. One definition of popular culture is that, 'Popular culture is the set of practices, beliefs, and objects that embody the most broadly shared meanings of a social system. It includes media objects, entertainment and leisure, fashion and trends, and linguistic conventions, among other things.' [13] Due to its openness, popular culture provides favourable conditions for the public to actively participate in the production and development of art and culture. The universality of popular culture and the popularisation of art contribute to the mixture of culture and commerce and the reestablishment of aesthetic values and standards of contemporary art. Due to the strong associations of popular culture and daily life, the influence and impact of appropriation require attention and research.

In 2018, a video named Everything can be Supreme was broadcast over one billion times on Tik Tok and Weibo (Chinese social media applications), making it the most popular video of the year. The scenes and the brand logo Supreme in this video display striking contrasts. The video showed people riding pigs, a news presenter doing a sexual dance in fashionable clothes, a person wearing The Monkey King (a character in classical Chinese work of literature Journey to the West) mask and hung around his neck as he continuously shook his body. In the video, the Supreme logo was appropriated in terms of its font and colour. In addition, the background music in this video was anappropriation from well-known anti-war song Zombie, released by Irish band the Cranberries in 1994. In order to cater to visual effects of the video, the melody and rhythm were adapted, and the original message of resisting war and striving for peace disappeared instantly.

This game of appropriation involved the coercion of commerce, media, and the public. The strong brand image of Supreme is linked closely to this phenomenon. First of all, the logo of Supreme (white text on a red background) is not original. It is was designed based on the work I Buy So I Am 
Here by artist Barbara Kruger. Secondly, as a popular brand, Supreme has cooperated with internationally well-known brands such as LV, Nike, Vans, etc. The novelty and exclusivity of its marketing strategies have led to the increasing popularity and dominant role in youth and popular culture. Interestingly, the products this brand sell range from clothing, bags and suitcases to daily necessities, including some unexpected products, such as red-clay bricks, money guns and even coffins. Even though prices are considerably higher than the average market price, they sell out quickly, once released. Finally, Supreme stimulates discourse in response to social, cultural, and political issues, increasing attention and popularity in a short period of time.

The increasingly close relationship between appropriation and commerce is likely to cause a situation where appropriation becomes an industrial product in the context of consumer culture. Just as Jean Baudrillard pointed out, 'pop regards itself as homogeneous with this immanent order of signs: homogeneous with their industrial, mass production and hence with the artificial, manufactured character of the whole environment, homogeneous with the spatial saturation and simultaneous culturalized abstraction of this new order of things.' [14] From his standpoint, the essence of pop culture is a plethora of signs, which induce public indulgence in a world created by advertising and industry.

The context of the postmodern society affects creations of popular culture. According to postmodern theorist Frederick Jameson, copy, repetition, reconstruction constitutes the internal order of consumer-culture production under the influence of postmodernism, finally forming a culture without depth. It brings a situation where aesthetic creations are formed by combinations of consumption and popular culture. However, it is likely to cause the misconception that appropriation can act as an artistic overcoat with a sanctifying function. Original works can be conceptualised, and appropriation can be adopted endlessly. Baudrillard suggested that, 'The majority of contemporary art has attempted to do precisely that by confiscating banality waste and mediocrity as values and ideologies. These countless installations and performances are merely compromising with the state of things, and with all the past forms of art history. Raising originality, banality and nullity to the level of values or even to perverse aesthetic pleasure.' [15] The positive aspect presented by appropriation is the ability to learn from well-known artworks. However, those artistic creations are not limited to this process. The excessive usages of appropriation in artistic creations make the process of creations indifferent and banal.

\section{Conclusion}

Appropriation is an inseparable part in art history and contemporary society. It is an effective artistic technique to reflect on pre-existing objects, images and artworks. It also encourages artists and the public to challenge long-held artistic styles and thoughts and excavate connotations and meanings of classical works. But appropriation should not be viewed as a shortcut to create works of art and not all works of appropriation can be viewed as artworks. To conclude, the essence of the appropriation is to explore more creative and original works rather than indulge in the endless indistinguishable repetition of this artistic technique.

\section{References}

[1] Wilson, S; Jessica, L. (2008). The Tate Guide to Modern Art Terms, London: Tate Publishing Ltd, 2008. p20.

[2] Sabur R. (2019). Banana duct-taped to a wall sells for $\$ 120,000$ at Art Basel. https://www.telegraph.co.uk/news/2019/12/06/banana-duct-ta ped-wall-sells-120000-art-basel/.(accessed: Oct 22, 2018).

[3] Farra, E. Maurizio Cattelan on "The Artist Is Present," His Mind-Bending New Exhibition With Alessandro Michele in.

[4] Danto, A, C. (1995). After The End of Art. Princeton: Princeton University Press. p10.

[5] Ibid.

[6] Reyburn, S. Jeff Koons 'Rabbit' Sets Auction Record for Most Expensive Work by Living Artist. https://www.nytimes.com/2019/05/15/arts/jeff-koons-rabbit-a uction.html. (accessed: May 15, 2019).

[7] Thierry de Duve. (1996). Kant after Duchamp. Cambridge, Massachusetts: The MIT Press. p13.

[8] Barthes R. (1967). Elements of Semiology. New York: Jonathan Cape Ltd. p41.

[9] Cabanne, P. (1987). Dialogues with Marcel Duchamp. The USA: Da Capo Press. p48.

[10] Heidegger, M. (2005) Introduction to Phenomenological Research. Trans by Daniel O. Dahlstrom. USA: Indiana University Press. p87.

[11] Heidegger, M. (1927). Basic Writings, From Being and Time to The Task of Thinking (1964) revised \& expanded edition, edited by David Farrel Krell, Harper SanFransisco. p202.

[12] Crimp, D. (1983). 'Appropriating appropriation', in Image Scavengers, Philadelphia: Institute of Contemporary Art. p126.

[13] Kidd, D. (2017). Popular Culture. https://www.oxfordbibliographies.com/view/document/obo-97 80199756384/obo-9780199756384-0193.xml (accessed: Feb 28, 2017).

[14] Baudrillard, J. (2017). The Consumer Society: Myths and Structure. revised edition. Sage. p218.

[15] Baudrillard, J. (2005). The Conspiracy of Art. Cambridge: The MIT Press. p21. 